\title{
Study of Different Variation of Height of Symmetric and Asymmetric Building by Linear Static and Dynamic Analysis Using STAAD Pro
}

\author{
Pratibha Nargatti and Abhija Patil
}

\begin{abstract}
The paper aim towards the analysis of Symmetric and Asymmetric building using a software STAAD.PRO. The two buildings are considered in the study, one is rectangular in shape and other is ' $L$ ' in shape and both are been analyzed by linear Static method and Response Spectrum method. The two plans are studied for different variation of height i.e., G+5, G+10, G+15 and $G+20$ and seismic properties are kept similar for both the buildings. The parameter evaluated are Base Shear, Story displacement, Story shear, Story drift and Time period. The manual calculation of Base shear is obtained and compared with the STAAD result as per code IS 1893:2002. The each parameter is studied for different height and checked the difference between Symmetric and Asymmetric building. The paper also includes what will be the effect, if the height of building increases due to a seismic analysis.
\end{abstract}

Keywords--- Base Shear, Response Spectrum Method, STAAD.PRO, Static Analysis, Time Period

\section{INTRODUCTION}

A $\mathrm{N}$ Earthquake is defined as rock formation are suddenly disturbed, a large amount of elastic energy released by a sudden slip on a fault and resulting vibration spread out in all direction from the source of disturbance. The Earthquake have been expected most disastrous thing. The cause of Earthquake is due to the geological faults, volcanic activity, nuclear test, landslides and mine blast. The building which don't meet the current seismic requirement and seismic design, which may suffer a damage during earthquake and may also suffer an extensive collapse if the ground is shaken by a severe motion. The Reinforced concrete frame building which are been used in many developed countries and in the Industrial countries and are popular in many hilly areas. In developed countries and in hilly areas reinforced concrete construction is more in use due to low initial cost compared to steel and composite. The paces which are situated in a Zone IV like which are in the junction of Alps-Himalaya and Circum Pacific are subjected to frequent Earthquake. The areas in Zone IV are often subjected to frequent Earthquake; Earthquake consists of horizontal and vertical movement of the Earth's surface. So it is necessary to consider structural design of building for seismic load, the seismic load is concerned with structural safety during major ground motion.

\section{MODELING IN STAAD}

\section{A. Structural Modeling}

Symmetric and Asymmetric building is analyzed by Static and Dynamic Analysis using a software STAAD.PRO V8i. The result obtained after analyzing using STAAD.PRO is represented by a graphically using MS office Excel.

\section{B. Data Analysis of RCC Structure}

Table 1: Data Analysis of RCC Structure

\begin{tabular}{|l|l|}
\hline PLAN DIMENSION & \\
Symmetric area & $1080 \mathrm{~m}^{2}$ \\
Asymmetric area & $810 \mathrm{~m}^{2}$ \\
\hline Foundation depth & $2.5 \mathrm{~m}$ \\
\hline Height of each floor & $3.15 \mathrm{~m}$ \\
\hline Parapet Height & $1.0 \mathrm{~m}$ \\
\hline Live load & $4.0 \mathrm{kN} / \mathrm{m}^{2}$ \\
\hline Zone factor & $\mathrm{IV}$ \\
\hline Importance factor & 1.5 \\
\hline Soil Condition & $\mathrm{Hard}$ \\
\hline Damping ratio & $5 \%$ \\
\hline Floor finish & $1.0 \mathrm{kN} / \mathrm{m}^{2}$ \\
\hline Density of concrete & $25 \mathrm{kN} / \mathrm{m}^{3}$ \\
\hline Density of masonry & $20 \mathrm{kN} / \mathrm{m}^{3}$ \\
\hline
\end{tabular}

C. Section Properties

\begin{tabular}{|l|l|l|l|}
\hline Plan area & Structure & Member Properties & Size $($ B $\times$ D $) \mathrm{mm}$ \\
\hline Symmetry & $\mathrm{G}+5$ & Beams & $300 \times 600$ \\
& & Column & $450 \times 450$ \\
& & Slab & 150 \\
\cline { 2 - 4 } & $\mathrm{G}+10$ & Beam & $300 \times 600$ \\
& & Column & $600 \times 600$ \\
& Slab & 150 \\
\cline { 2 - 4 } & $\mathrm{G}+15, \mathrm{G}+20$ & Beam & $300 \times 600$ \\
& & Column & $900 \times 900$ \\
& & Slab & 150 \\
\hline
\end{tabular}

\begin{tabular}{|c|c|c|c|}
\hline Plan area & Structure & Member Properties & Size $(B \times D) \mathrm{mm}$ \\
\hline \multirow{3}{*}{ Asymmetry } & $\mathrm{G}+5$ & $\begin{array}{l}\text { Beams } \\
\text { Column } \\
\text { Slab }\end{array}$ & $\begin{array}{l}300 \times 600 \\
450 \times 450 \\
150\end{array}$ \\
\hline & $\mathrm{G}+10$ & $\begin{array}{l}\text { Beam } \\
\text { Column } \\
\text { Slab }\end{array}$ & $\begin{array}{l}300 \times 600 \\
600 \times 600 \\
150\end{array}$ \\
\hline & $\mathrm{G}+15, \mathrm{G}+20$ & $\begin{array}{l}\text { Beam } \\
\text { Column } \\
\text { Slab }\end{array}$ & $\begin{array}{l}300 \times 600 \\
900 \times 900 \\
150\end{array}$ \\
\hline
\end{tabular}

Pratibha Nargatti, PG Student, S.G.B.I.T, Belagavi, E-mail:pratibha.civil10jce@gmail.com

Abhija Patil, Assistant Professor, S.G.B.I.T, Belagavi. DOI:10.9756/BIJMMI.8185 
D. Plan of Symmetric and Asymmetric Building

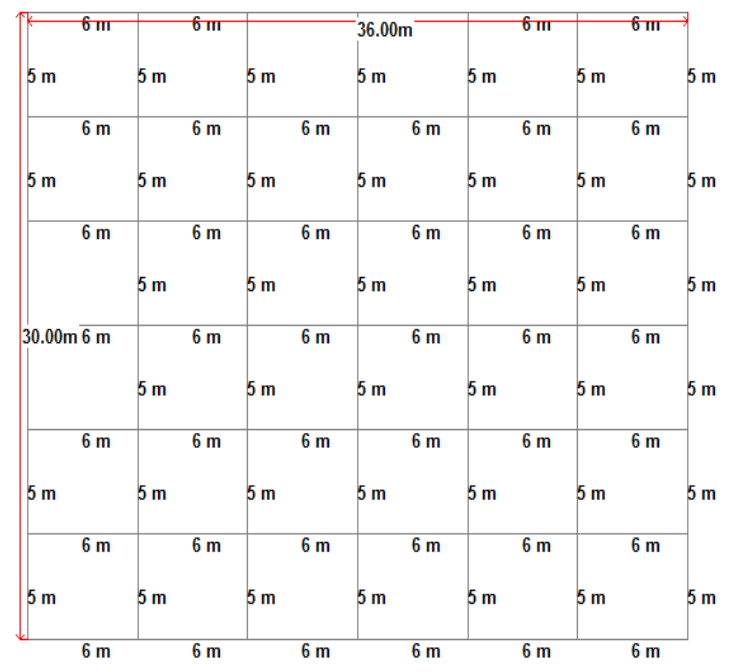

Figure 1: Plan of Symmetric Building

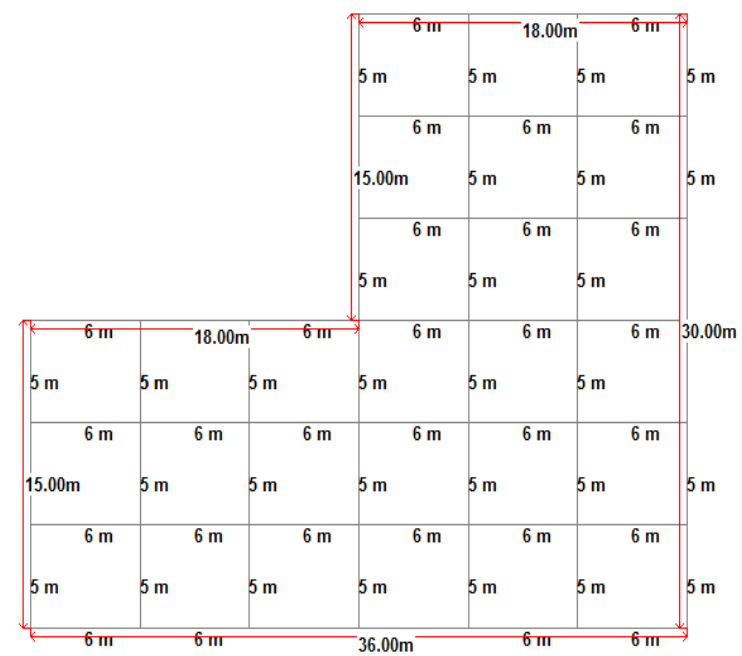

Figure 2: Plan of Symmetric Building

\section{E. Load Considered in Analysis}

\section{Dead Load}

- Wall Load $=$ Thickness of wall $\mathrm{x}$ (Height of floordepth of beam) $x$ Density of masonry $=0.23 \times(3.15$ 0.6) $\mathrm{x} 20=11.73 \mathrm{Kn} / \mathrm{m}$

- $\quad$ Parapet wall $=$ Thickness of wall $\mathrm{x}$ Height of parapet $\mathrm{x}$ Density of masonry $=0.23 \times 1.0 \times 20=4.6 \mathrm{kN} / \mathrm{m}$

- Floor Load $=($ Thickness of slab $\mathrm{x}$ Density of concrete $)+$ Floor finish $=(0.15 \times 25)+1=4.75 \mathrm{kN} / \mathrm{m}^{2}$

\section{Live Load}

- Floor Load for public building $=4 \mathrm{kN} / \mathrm{m}^{2}$

- Floor load at roof $=1.5 \mathrm{kN} / \mathrm{m}^{2}$

- As per IS 1893:2002 Clause no. 7.3.1, Table no.8, the live load considered for seismic weight is $50 \%$.

- Hence,

- Floor load for public building $=4 \times 0.5=2 \mathrm{kN} / \mathrm{m}^{2}$

- Floor load on roof $=1.5 \times .5=0.75 \mathrm{kN} / \mathrm{m}^{2}$

\begin{tabular}{|l|l|l|}
\hline Type & Load Combination & Name \\
\hline Primary & 1 & DL \\
\hline Primary & 2 & LL \\
\hline Primary & 3 & EQX \\
\hline Primary & 4 & EQZ \\
\hline Combination & 5 & $1.5 \mathrm{DL}$ \\
\hline Combination & 6 & $1.5(\mathrm{DL}+\mathrm{LL})$ \\
\hline Combination & 7 & $1.5(\mathrm{DL}+\mathrm{EQX}+)$ \\
\hline Combination & 8 & $1.5(\mathrm{DL}+\mathrm{EQX}-)$ \\
\hline Combination & 9 & $1.5(\mathrm{DL}+\mathrm{EQZ}+)$ \\
\hline Combination & 10 & $1.5(\mathrm{DL}+\mathrm{EQZ}-)$ \\
\hline Combination & 11 & $1.2(\mathrm{DL}+\mathrm{LL})$ \\
\hline Combination & 12 & $1.2(\mathrm{DL}+\mathrm{LL}+\mathrm{EQX}+)$ \\
\hline Combination & 13 & $1.2(\mathrm{DL}+\mathrm{LL}+\mathrm{EQX}-)$ \\
\hline Combination & 14 & $1.2(\mathrm{DL}+\mathrm{LL}+\mathrm{EQZ}+)$ \\
\hline Combination & 15 & $1.2(\mathrm{DL}+\mathrm{LL}+\mathrm{EQZ}-)$ \\
\hline Combination & 16 & $0.9 \mathrm{DL}+1.5 \mathrm{EQX}+$ \\
\hline Combination & 17 & $0.9 \mathrm{DL}+1.5 \mathrm{EQX}-$ \\
\hline Combination & 18 & $0.9 \mathrm{DL}+1.5 \mathrm{EQZ}+$ \\
\hline Combination & 19 & $0.9 \mathrm{DL}+\mathrm{EQZ}-$ \\
\hline
\end{tabular}

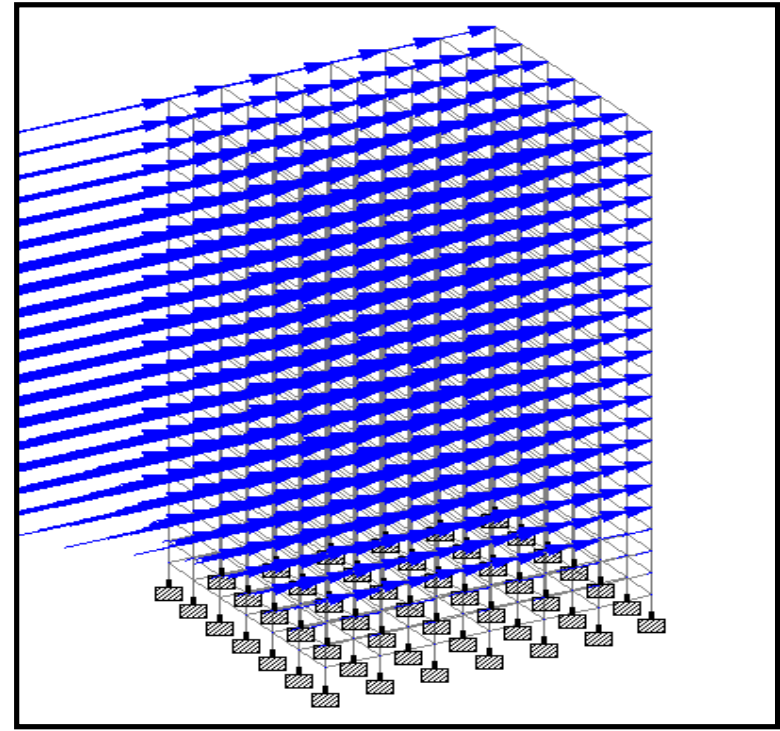

Figure 3: Earthquake Loading on Symmetric Building

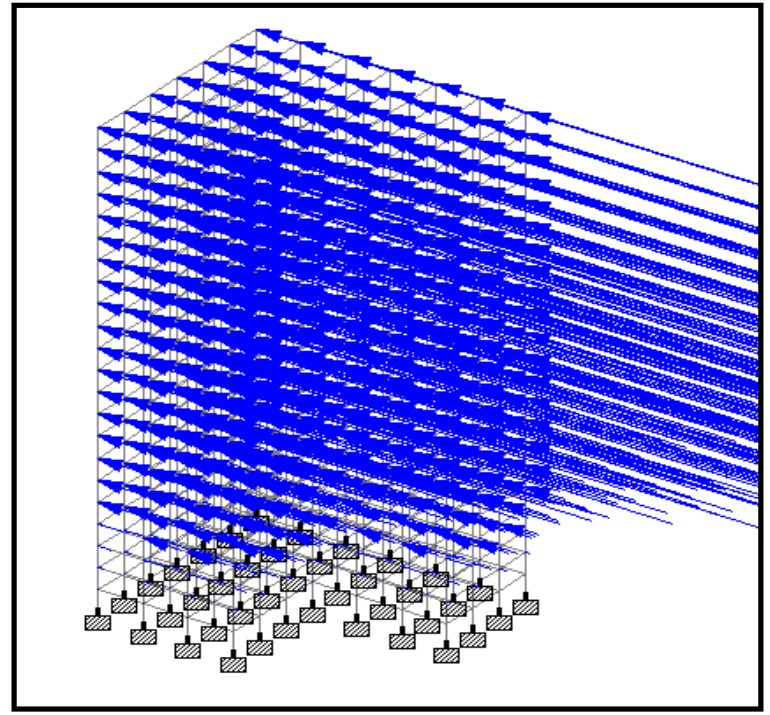

Figure 4: Earthquake Loading on Asymmetric Building 


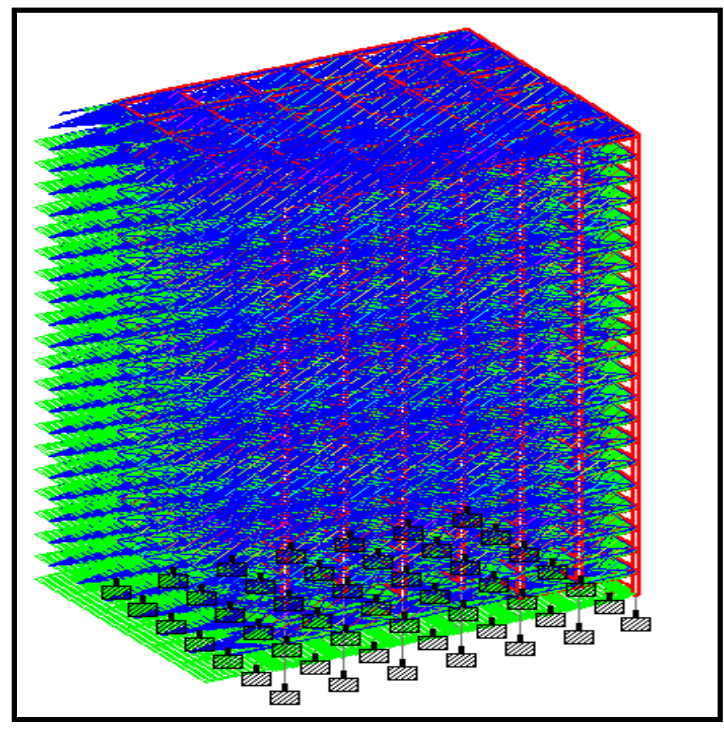

Figure 5: RSX Loading on Symmetric Building

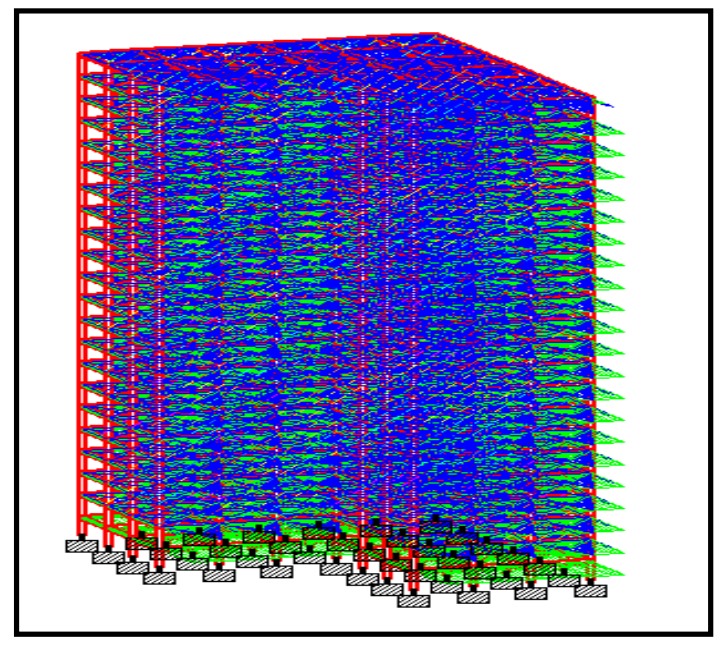

Figure 6: RSX Loading on Asymmetric Building

\section{RESULTS AND DISCUSSION}

\section{A. Base Shear}

Base shear is the force that occur at the base of the building due to an earthquake and it depends on the seismic zone, height and shape of building.

\section{Manual Calculation of Base Shear}

1. Calculation of Seismic Weight of Symmetric and Asymmetric Building

$\mathrm{G}+5$ storey symmetric building

\section{Roof Calculation}

Slab load $=(36 \times 30 \times 4.75)=5130 \mathrm{KN}$

Live load $=(36 \times 30 \times 0.75)=810 \mathrm{KN}$

Beam $=(0.3 \times 0.6 \times 6 \times 25) \times 42+(0.3 \times 0.6 \times 5 \times 25) \times$ $42=2079 \mathrm{KN}$

Column $=(0.45 \times 0.45 \times 1 \times 25 \times 24)=121.5 \mathrm{KN}$

Wall $=(0.23 \times 1 \times 6 \times 20 \times 12)+(0.23 \times 1 \times 5 \times 20 \times 12)$ $=607.2 \mathrm{KN}$
Total $=8140.5 \mathrm{KN}$

\section{Storey Calculation}

Slab load $=(36 \times 30 \times 4.75)=5130 \mathrm{KN}$

Live load $=(36 \times 30 \times 2)=2160 \mathrm{KN}$

Beam $=(0.3 \times 0.6 \times 6 \times 25) \times 42+(0.3 \times 0.6 \times 5 \times 25) \times$ $42=2079 \mathrm{KN}$

Column $=(0.45 \times 0.45 \times 3.15 \times 25 \times 49)=781.4 \mathrm{KN}$

Wall $=(0.23 \times 2.55 \times 6 \times 20 \times 42)+(0.23 \times 2.55 \times 5 \times 20$ $\mathrm{x} 42)=5419.26 \mathrm{KN}$

Total $=15569.65 \mathrm{KN}$

Total 5 Storey calculation $=15569.65 \times 5=77848.25 \mathrm{KN}$

Ground Level

Beam $=(0.3 \times 0.6 \times 6 \times 25) \times 42+(0.3 \times 0.6 \times 5 \times 25) \times$ $42=2079 \mathrm{KN}$

Column $=(0.45 \times 0.45 \times 3.15 \times 25 \times 49)=781.4 \mathrm{KN}$

Wall $=(0.23 \times 2.55 \times 6 \times 20 \times 42)+(0.23 \times 2.55 \times 5 \times 20$ $\mathrm{x} 42)=5419.26 \mathrm{KN}$

Total $=8279.65 \mathrm{KN}$

Total Seismic Weight $=94268.4 \mathrm{KN}$

G+5 storey Asymmetric building

Area of the Building $=(36 \times 30)-(18 \times 15)=810 \mathrm{~mm}^{2}$

Roof Calculation

Slab load $=(810 \times 4.75)=3847.5 \mathrm{KN}$

Live load $=(810 \times 0.75)=607.5 \mathrm{KN}$

Beam $=(0.3 \times 0.6 \times 6 \times 25) \times 33+(0.3 \times 0.6 \times 5 \times 25) \times$ $33=1633.5 \mathrm{KN}$

Column $=(0.45 \times 0.45 \times 1 \times 25 \times 24)=121.5 \mathrm{KN}$

Wall $=(0.23 \times 1 \times 6 \times 20 \times 12)+(0.23 \times 1 \times 5 \times 20 \times 12)$ $=607.2 \mathrm{KN}$

Total $=6817.2 \mathrm{KN}$

\section{Storey Calculation}

Slab load $=(810 \times 4.75)=3847.5 \mathrm{KN}$

Live load $=(810 \times 2)=1620 \mathrm{KN}$

Beam $=(0.3 \times 0.6 \times 6 \times 25) \times 33+(0.3 \times 0.6 \times 5 \times 25) \times$ $33=1633.5 \mathrm{KN}$

Column $=(0.45 \times 0.45 \times 3.15 \times 25 \times 40)=637.8 \mathrm{KN}$

Wall $=(0.23 \times 2.55 \times 6 \times 20 \times 33)+(0.23 \times 2.55 \times 5 \times 20$ $\mathrm{x} 4 \mathrm{x} 33)=4257.99 \mathrm{KN}$

Total $=11996.86 \mathrm{KN}$

Total 5 Storey calculation $=11996.86 \times 5=59984.3 \mathrm{KN}$ 


\section{Ground Level}

Beam $=(0.3 \times 0.6 \times 6 \times 25) \times 33+(0.3 \times 0.6 \times 5 \times 25) \times$ $33=1633.5 \mathrm{KN}$

Column $=(0.45 \times 0.45 \times 3.15 \times 25 \times 40)=637.8 \mathrm{KN}$

Wall $=(0.23 \times 2.55 \times 6 \times 20 \times 33)+(0.23 \times 2.55 \times 5 \times 20$ $\mathrm{x} 33)=4257.99 \mathrm{KN}$

Total $=6529.36 \mathrm{KN}$

Total Seismic Weight $=73330.86 \mathrm{KN}$

2. Design of Seismic Base Shear

The design seismic base shear as per IS code 1893:2002,

$$
\mathrm{V}_{\mathrm{b}}=\mathrm{A}_{\mathrm{h}} \mathrm{x} \mathrm{w}
$$

$A_{h}=$ Design horizontal acceleration

$\mathrm{w}=$ Seismic weight of building

$$
A_{h}=(Z / 2) \times(I / R) \times\left(S_{a} / g\right)
$$

$Z=0.24$

For important structure, $\mathrm{I}=1.5$

$\mathrm{R}=5, \mathrm{~S}_{\mathrm{a}} / \mathrm{g}=$ Average response acceleration coefficient

Time period is required to calculate for average response acceleration coefficient. Stiffness of masonry infill is neglected in time period

$$
\mathrm{T}=0.075 \mathrm{xh}^{0.75}
$$

For $\mathrm{G}+5$ storey building

Height of building for 5 storey $=18.9 \mathrm{~m}$

Time period for symmetric and asymmetric structure is,

$$
\mathrm{T}=0.075 \mathrm{x}(18.9)^{0.75}=0.679 \mathrm{sec}
$$

From IS 1893:2002 page no.16

$$
\begin{gathered}
\mathrm{S}_{\mathrm{a}} / \mathrm{g}=1.47 \\
\mathrm{~A}_{\mathrm{h}}=(0.24 / 2) \times(1.5 / 5) \times(1.47)=0.529
\end{gathered}
$$

Table 2: Comparison of Base Shear of Manual and STAAD Result of a Symmetric Building

\begin{tabular}{|l|l|l|}
\hline Structure & $\begin{array}{l}\text { Manual Result of Base } \\
\text { Shear }(\text { KN })\end{array}$ & $\begin{array}{l}\text { STAAD Result of Base } \\
\text { Shear }(\text { KN })\end{array}$ \\
\hline $\mathrm{G}+5$ & 4996.22 & 5169.74 \\
\hline $\mathrm{G}+10$ & 6042.10 & 6089.43 \\
\hline $\mathrm{G}+15$ & 7326.46 & 7330.57 \\
\hline $\mathrm{G}+20$ & 7824.86 & 7797.22 \\
\hline
\end{tabular}

Table 3: Comparison of Base Shear of Manual and STAAD Result of an Asymmetric Building

\begin{tabular}{|l|l|l|}
\hline Structure & $\begin{array}{l}\text { Manual Result of Base } \\
\text { Shear }(K N)\end{array}$ & $\begin{array}{l}\text { STAAD Result of Base } \\
\text { Shear }(K N)\end{array}$ \\
\hline $\mathrm{G}+5$ & 3886.53 & 3976.61 \\
\hline $\mathrm{G}+10$ & 4665.9 & 4699.82 \\
\hline $\mathrm{G}+15$ & 5696.77 & 5686.08 \\
\hline $\mathrm{G}+20$ & 6082.38 & 6051.19 \\
\hline
\end{tabular}

\section{B. Time Period}

The height of building and the behavior of different shapes of building is influenced by the Natural period. The Natural period is known by a response spectrum method and hence it is a convenient method for evaluation of a response of the structure. The Time period obtained by a Symmetric and
Asymmetric building for different height is shown in below tables and graphs.

Table 4: Comparison of Time period G+5 Building

\begin{tabular}{|l|l|l|}
\hline Mode & Symmetric & Asymmetric \\
\hline & sec & sec \\
\hline 1 & 1.38 & 1.34 \\
\hline
\end{tabular}

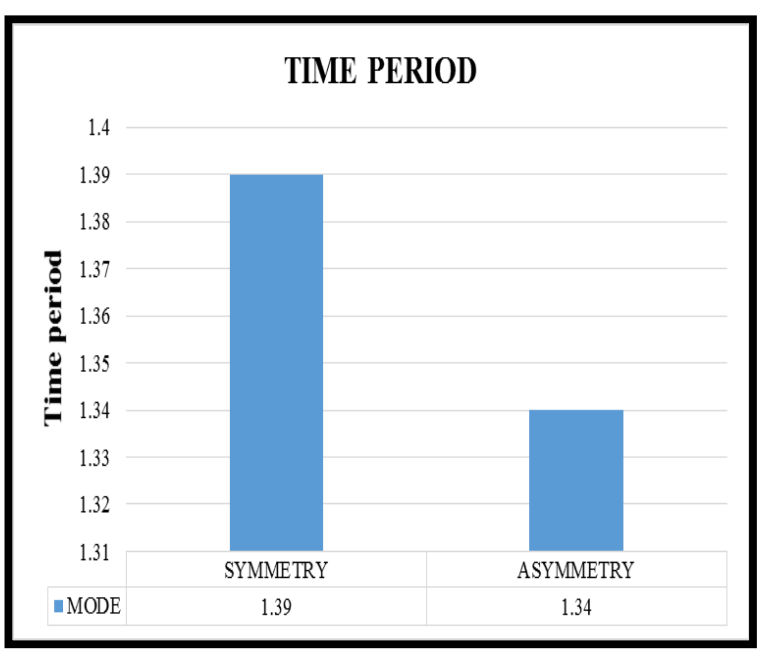

Figure 7: Graph of time Period of G+5 Storey

Table 5: Comparison of Time Period G+10 Building

\begin{tabular}{|l|l|l|}
\hline Mode & Symmetric & Asymmetric \\
\hline & sec & sec \\
\hline 1 & 2.06 & 2.04 \\
\hline
\end{tabular}

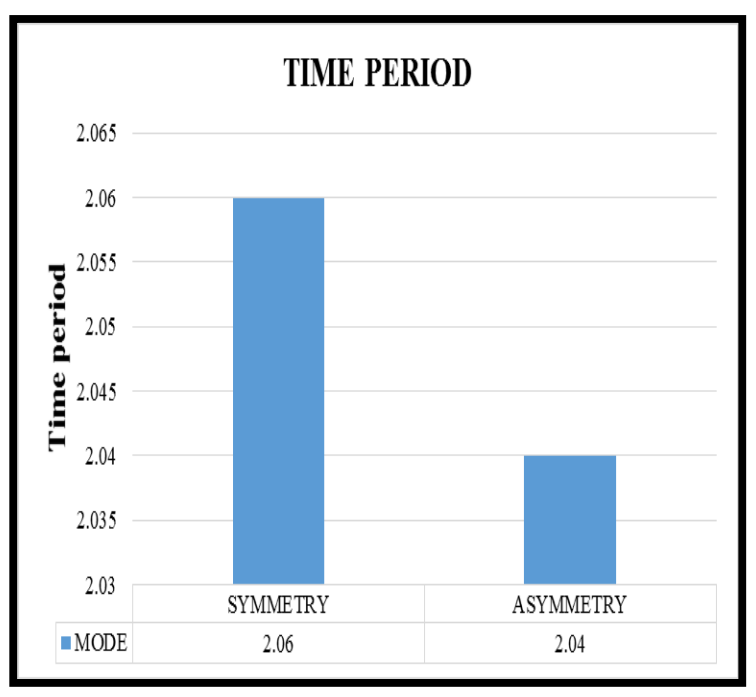

Figure 8: Graph of Time Period of G+10 Storey

Table 6: Comparison of Time period G+15 Building

\begin{tabular}{|l|l|l|}
\hline Mode & Symmetric & Asymmetric \\
\hline & sec & sec \\
\hline 1 & 2.74 & 2.72 \\
\hline
\end{tabular}




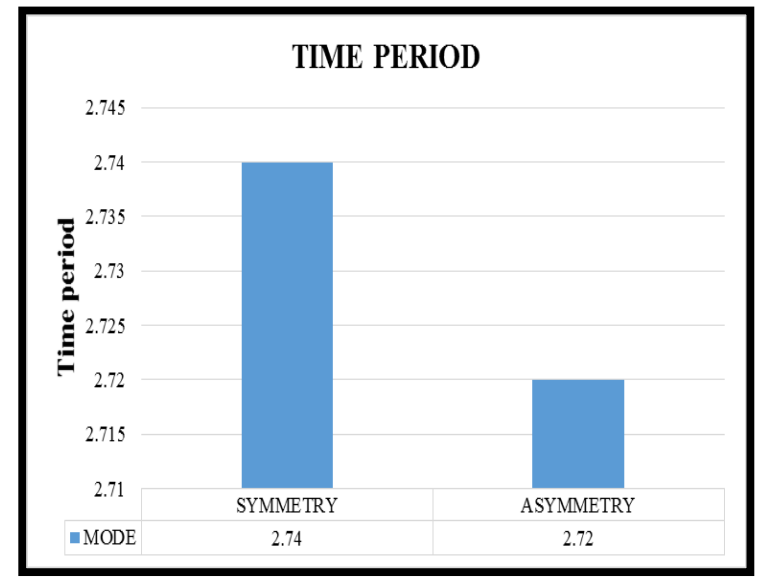

Figure 9: Graph of Time Period of G+15 Storey

Table 7: Comparison of Time Period G+20 Building

\begin{tabular}{|l|l|l|}
\hline Mode & Symmetric & Asymmetric \\
\hline & sec & sec \\
\hline 1 & 3.66 & 3.65 \\
\hline
\end{tabular}

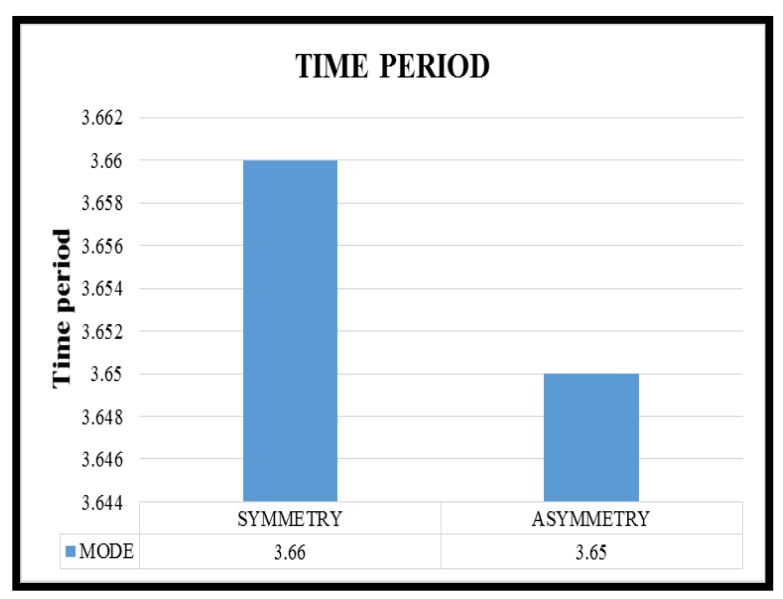

Figure 10: Graph of Time Period of G+20 Storey

Fom graphs and tables of Time period it is observed that, Fig 5.1 shows the time period of Symmetric building G+5 increases by $0.04 \mathrm{sec}$ compared to Asymmetric Building G+5. Fig 5.2 and Fig 5.3 The time period of Symmetric Building $\mathrm{G}+10$ and $\mathrm{G}+15$ increases by $0.02 \mathrm{sec}$ compared to Asymmetric building $\mathrm{G}+10$ and $\mathrm{G}+15$. Fig 5.4 The time period of Symmetric building G+20 increases by $0.01 \mathrm{sec}$ compared to Asymmetric building G+20. The increase of Time period is due to damping of structure and lateral interia force decreases due to increase in time period.

\section{CONCLUSION}

1. The Base Shear value obtained by manual analysis is less compare to the Software analysis.

2. The Base Shear value of Symmetric building is more compared to the Asymmetric building.

3. In Symmetric building the time period is more compare to Asymmetric building. The time period of Symmetric and Asymmetric building tries to match with each other when the height of building is increased.
4. The regular building is preferred more compared to irregular building as the irregular building undergoes more deformation.

\section{REFERENCES}

[1] Mohd Zain Kangda and Manohar D. Mehare, "Study of base shear and story drift by dynamic analysis" International Journal of Engineering and Innovative Technology, 2015.

[2] Dr. Vinod Hosur, "Earthquake Resistant Design of Building Structures" Wiley, India.

[3] Sharath Irappa Kammar and Tejas D. Joshi, "Nonlinear static analysis of symmetric building with and without shear wall" International Research Journal of Engineering and Technology, 2015.

[4] Mahesh N. Patil and Yogesh N. Sonawane, "Seismic Analysis of Multistoried Building" International Journal of Engineering and Innovative Technology, 2015.

[5] Hamraj and Mohammed Moiz Khan "Seismic Performance Evaluation of RC buildings with Vertical Irregularities subjected to Biaxial Excitation", IJSET, 2015.

[6] Mohammed Irfan, Dr. Sunandan and K. Mythili, "Evaluation of Seismic Response of Symmetric and Asymmetric Multistoried Building" International Journal of Science Engineering and Advance technology, 2014.

[7] B. Rajesh, Mr. Sadat Ali Khan, et al., "Comparison of linear static and dynamic analysis of multistoried building with plan irregularities", International Journal of Scientific Engineering and Applied Science, 2015.

[8] Anirudh Gottala, Dr. Shaikh Yajdhani et al. "Comparative Study of Static and Dynamic Seismic Analysis of a Multistoried Building", International Journal of Science Technology and Engineering, 2015.

[9] Ni Ni Win and Kyaw Lin Htat, "Comparative study of static and dynamic analysis of Irregular Reinforced Concrete building due to Earthquake", International Journal of Scientific Engineering and Technology Research, 2014.

[10] Dr. Savita Maru and Mohit Sharma, "Dynamic Analysis of Multistoried Building", Journal of Mechanical and Civil Engineering, 2014.

[11] S.S. Patil, S.A. Ghadge, C.G. Konapure and C.A Ghadge, "Seismic Analysis of High Rise Building by Response Spectrum Method", International Journal of Computational Engineering Research, Vol. 3, No.3, Pp.272-279, 2013.

[12] IS 1893:2002, "Indian Standard Criteria for Earthquake Resistant of design of structures Part-1-General Provisions and building", Bureau of Indian Standard, New Delhi, India. 